ROCZNIKI PEDAGOGICZNE

Tom 13(49), numer $4-2021$

DOI: http://doi.org/10.18290/rped21134.11

RENATA DONIEC

\author{
RODZINA I RODZICIELSTWO \\ W KULTURZE REALNEGO SOCJALIZMU - \\ MIĘDZY IDEOLOGIĄ A CODZIENNOŚCIĄ
}

\begin{abstract}
WSTĘP
Rodzicielstwo jako zjawisko jednostkowe i społeczne jest zjawiskiem kulturowym, osadzonym w kulturze danego społeczeństwa, środowiska społecznego i rodziny. Kultura stanowi zaś właściwy dla członków danej społeczności sposób życia, wzorzec działania i myślenia wyznaczający i regulujący wybrane aspekty życia ludzi oraz nadający im określony sens i znaczenie. W odniesieniu do rodziny, wyznacza ona i reguluje sposób życia, działania i myślenia m.in. w różnych sferach życia rodzinnego, np. w małżeństwie, rodzicielstwie, wychowywaniu potomstwa, pełnieniu ról rodzinnych itp. Między rodziną a kulturą zachodzą różne podobieństwa i zależności. Zarówno rodzinę jak i kulturę cechuje m.in. zmienność i różnorodność oraz systemowy charakter. Rodzinę i kulturę łączy zjawisko dziedziczenia, przekazywanie treści drogą socjalizacji, jak również wykonywanie funkcji zabezpieczających i stabilizujących w swoich środowiskach. Niekiedy jednak kulturę i rodzinę w ramach jednej społeczności charakteryzować może odmienny zbiór norm i wartości (tzw. układ aksjonormatywny), odmienny zbiór przekonań, poglądów, idei, sposobów myślenia, znaczeń (tzw. układ symboliczny), jak również odmienny zbiór obiektów, urządzeń, umiejętności praktycznych (tzw. układ materialno-techniczny) (Sztompka, 2002, s. 233). Wtedy między kulturą a rodziną wystąpić mogą różne niespójności, sprzeczności, a nawet całkowity rozdźwięk utrudniający lub uniemożliwiający wzajemną identyfikację. Wówczas rodzina może w różnym stopniu identyfikować się z otaczającą kulturą.
\end{abstract}

Dr Renata Doniec - Zakład Pedagogiki Społecznej i Andragogiki, Instytut Pedagogiki Uniwersytetu Jagiellońskiego; adres do korespondencji: ul. Batorego 12, 31-135 Kraków; e-mail: renata. doniec@uj.edu.pl; ORCID: https://orcid.org/0000-0003-0755-1537 
Generalnie między kulturą danej społeczności a funkcjonującą w niej kulturą konkretnej rodziny zachodzić mogą różne stopnie identyfikacji. Może to być identyfikacja kompletna i bezwarunkowa (np. z kulturą chrześcijańską, laicką), albo też częściowa lub wcale nie występować (np. z kulturą socjalistyczną). Gdy między kulturą rodzinną a kulturą społeczeństwa zachodzą sprzeczności, ludzie czują się zdezorientowani, doświadczają ambiwalencji, tracą poczucie tego, co dobre a co złe. Mogą pojawić się takie zjawiska, jak: dysonans kulturowy, kryzys czy trauma kulturowa, w przypadku gdy zachodzące zmiany są gwałtowane i całościowe. Efektem tych zjawisk jest coraz większe rozchodzenie się kultury danej społeczności i kultury konkretnej rodziny, prowadzące do osłabienia rodziny jako instytucji oraz dezorientacji kulturowej jej członków, w tym niepewności w wyborze właściwych zachowań oraz poczucie „niekompetencji cywilizacyjnej” (Sztompka, 2002, s. 461).

Powyższe zjawiska widoczne były w Polsce po 1945 roku, kiedy nastąpiła gwałtowana zmiana kulturowa polegająca na przechodzeniu z przedwojennej kultury demokratycznej w kulturę realnego socjalizmu. Zmiana ta miała charakter radykalny, wszechstronny i głęboki, sterowany odgórnie polityką komunistycznej władzy. Nowa kultura zbudowana na doktrynie marksistowskiej, odwołująca się do myśli Marksa, Engelsa, Lenina i Stalina, miała docelowo wchłonąc całą dotychczasową chrześcijańską kulturę i tradycję. W wyniku tych działań kultura $\mathrm{w}$ Polsce funkcjonowała $\mathrm{w}$ dwóch wymiarach, czyli w wymiarze oficjalnym i nieoficjalnym, które określone zostały przez Jana Lutyńskiego jako „oficjalna nadrzeczywistość” i „codzienna rzeczywistość” (Lutyński, 1990, s. 179-194). U źródeł pierwszego wymiaru leżała marksistowska koncepcja kultury (w wydaniu Marksa, Engelsa, Lenina i Stalina), a u podstaw drugiego koncepcja chrześcijańska, znajdująca wyraz w odwiecznym nauczaniu Kościoła. Te dwie odmienne wizje kultury, koncepcje społeczeństwa i rodziny przenikały się wzajemnie, kształtując świadomość i życie polskiego społeczeństwa. W takich warunkach rodzina polska zmuszona była funkcjonować równocześnie w dwóch wymiarach, tj. w „oficjalnej nadrzeczywistości” i w „codziennej rzeczywistości”. Pierwszy wymiar był narzucony odgórnie,, przez partię, politykę, celową indoktrynację, propagandę, edukację i wymagał od jednostki funkcjonowania zgodnie z światopoglądem socjalistycznym. Drugi wymiar tworzony był oddolnie, spontanicznie przez społeczeństwo, zwykłych ludzi w toku codziennego życia, według realiów codzienności, tj. w warunkach zależności, niedoborów, lęków i szarości (Doniec, 2019 s. 171-192). Te dwa wymiary kultury prezentowały dwie odrębne rzeczywistości, których wpływy rzadko się pokrywały i najczęściej były rozbieżne. Dlatego też kształtowały one inne zachowania, myślenie, posługiwały się innym językiem oraz rządziły się innymi prawami. „Oficjalna nadrzeczywistość” w swoich dzia- 
łaniach stosowała różne strategie manipulacji, osłabiała struktury poznawcze, wypaczała myślenie i psychikę jednostek, generowała postawy uległe i bierne. „Codzienna rzeczywistość" budziła natomiast postawy adaptacyjno-obronne, buntu, czynnego oporu (np. różne strategie przetrwania), zaangażowania w zmianę, ale także biernego przystosowania. Obydwa wymiary posiadały inne wizje i oczekiwania wobec rodziny. W kulturze oficjalnej rodzina stanowiła swoisty projekt ideologiczno-polityczny rozpowszechniany drogą propagandy i indoktrynacji. Przez cały okres trwania PRL był on nie tylko egzemplifikacją marksistowskiej koncepcji rodziny, ale też mocno powiązany z aktualną linią polityczną partii. Związek propagowanego modelu rodziny z polityką najbardziej widoczny okazał się w latach stalinizmu, gdy zachodził proces tworzenia podstaw socjalistycznego państwa. Zalecany wówczas najbardziej skrajny totalitarno-produkcyjny model rodziny zakładał jej całkowite oddanie budowaniu „nowej rzeczywistości”. Rodzina i życie prywatne nie miały być w tamtych latach dla człowieka ważne. Liczyła się tylko praca na rzecz nowej, socjalistycznej ojczyzny. Tradycyjne rozumienie domu i wartości rodzinnych próbowano zastąpić myśleniem o ojczyźnie jako wspólnym domu. Życie rodzinne miało zostać przeniesione na teren fabryki i organizacji partyjnych. Jedyną akceptowaną funkcją rodziny była prokreacja, która oznaczała dostarczanie nowych budowniczych socjalizmu. Takie upolitycznienie i zideologizowanie rodziny osłabło po 1956 roku, ale nadal - w kolejnych dekadach - uważano, iż zasadniczą rolą rodziny jest budowanie socjalistycznego, a w przyszłości komunistycznego państwa. Pomimo iż w latach 60. i 70. propagowany odgórnie model rodziny nabierał coraz więcej cech nowoczesnej rodziny nuklearnej w ujęciu Talcota Parsonsa, czyli akcentował aspekty emocjonalno-integracyjne rodziny i bliższy był społecznym oczekiwaniom, to nadal pełnił on instrumentalną funkcję w polityce państwa. Miał on bowiem umacniać ideologię i politykę partii i w jej duchu - pod przewodnictwem szkoły - przygotowywać młode pokolenie do budowania socjalizmu w kraju. Model rodziny socjalistycznej był zatem instrumentem wykorzystywanym do spraw politycznych, skłaniającym obywateli do akceptacji wszelkich poczynań władzy w zakresie polityki gospodarczej, społecznej, demograficznej, kulturalnej itp. Manipulacja poszczególnymi elementami tego modelu, np. prokreacją, aktywnością zawodową kobiety, wychowywaniem dzieci - stosowana w mediach - miała przekonywać obywateli, że tylko taki model rodziny warunkuje osiągnięcie sukcesu w życiu (zwłaszcza kobietom i dzieciom) w przeciwieństwie do modelu rodziny kapitalistycznej, burżuazyjnej i chrześcijańskiej bazujących na wyzysku słabszych członków rodziny, niesprawiedliwości i fałszywej świadomości. Kluczem do sukcesu rodziny socjalistycznej miało być pełne podporządkowanie się (konformizm i adaptacja) celom politycznym panującej władzy. Wicedyrektor departamentu w Ministerstwie 
Oświaty i Wychowania w latach 70. Mieczysław Misiorny-Fitz, tak ujmował istotę funkcjonowania rodziny socjalistycznej:

Istotą rodziny socjalistycznej jest zgodność celów wszystkich jej członków z celami społeczeństwa, umiejętność godzenia interesów własnych z interesem społecznym, współzależność rozwoju i pomyślności społeczeństwa i państwa socjalistycznego z rozwojem i szczęściem rodziny (Kosterkiewicz, 1976, s. 87).

Taka socjalistyczna wizja rodziny nie znajdowała zazwyczaj odzwierciedlenia w praktyce codziennego życia. Ono bowiem toczyło się w przywiązaniu do tradycyjnego modelu rodziny i chrześcijańskich wartości. Dominacja tradycyjnego myślenia o rodzinie silniejsza była na wsi, gdzie wpływy nowej ideologii docierały z opóźnieniem i trudniej się zakorzeniały. Wieś ze względu na silniejsze przywiązanie do nauki Kościoła wykazywała większą odporność na laicyzację i socjalistyczną indoktrynację. W miastach, zwłaszcza dużych, akceptacja dla wpływów nowej ideologii w sferze życia rodzinnego była dużo większa, na co wskazywały takie zjawiska, jak: rosnąca liczba rozwodów, osłabienie kondycji moralnej rodziny, znaczne ograniczenie dzietności, czy masowa, wielozmianowa praca zawodowa kobiet-matek $^{1}$ (Kurzynowski, 2000, s. 194).

Ocenę tę potwierdza Memoriał Episkopatu Polski skierowany do Rządu Polskiej Rzeczypospolitej Ludowej z dnia 8 lutego 1978 roku, w którym dokonano szerokiej diagnozy warunków życia rodziny. Według opinii Prymasa Kardynała Stefana Wyszyńskiego polityka państwa i wpływy ideologii marksistowskiej doprowadziły w latach 70. do poważnego kryzysu rodziny, do którego przejawów zaliczono: osłabienie znaczenia małżeństwa i norm moralnych w rodzinie, spadek dzietności, pojawienie się lęku przed posiadaniem dziecka, zanikanie kultury rodzicielstwa i niską jakość kultury wychowawczej rodziców. Za przejawy kryzysu rodziny uznano też wzrost postaw egoistycznych oraz aspołecznej konsumpcji, jak również zjawisko izolowania się rodziny od społeczeństwa, zamykanie się we własnym kręgu i niechęć do nawiązywania szerszych kontaktów społecznych (Memoriał Episkopatu Polski 1978, s. 2). Wymienione oznaki kryzysu kondycji rodziny były także wynikiem trudnych warunków, jakich doświadczali ludzie w codziennym życiu w całym okresie PRL. W doświadczeniach wielu rodzin było to życie w warunkach ciągłej biedy, drożyzny, niedoborów, bylejakości, tymczasowości, w poczuciu bezsensu, wegetacji i braku perspektyw. Dla dużej części społeczeństwa niosło ono rozczarowanie i utratę sił, ale dla pewnych grup, przed wojną zmarginalizowanych, stwarzało poczucie awansu cywilizacyjnego

${ }^{1}$ Udział kobiet zamężnych wśród ogółu zatrudnionych w Polsce był obok ZSRR najwyższy na świecie. W 1950 roku wynosił on $18 \%$, w 1970 roku $-62 \%$, a pod koniec lat 80 . około $70 \%$. 
i poprawę jakości życia (Doniec, 2019, s. 171-192). Bez względu jednak na warunki społeczno-ekonomiczne, rodzina postrzegana była w codziennym życiu jako najważniejszy czynnik stabilizacji życiowej oraz azyl przed światem zewnętrznym interpretowanym jako wrogi (Świda, 1982, s. 219). Stanowić miała ona alternatywę i ochronę przed istniejącą rzeczywistością, czyli kulturą oficjalną ( $\mathrm{tj}$. „oficjalną nadrzeczywistością"). Cały ten kontekst kulturowo-społeczny tworzony przez ideologię, politykę oraz codzienność oddziaływał nie tylko kulturę rodziny, ale również wyznaczał ramy dla rozwoju rodzicielstwa w całym okresie PRL, w tym stosunek do norm i wartości związanych z posiadaniem dziecka, sens i znaczenie nadawane rolom rodzicielskim oraz obszar umiejętności praktycznych.

\section{ZAŁOŻENIA TEORETYCZNO-METODOLOGICZNE}

Przedstawiony powyżej zarys uwarunkowań kulturowych i społecznych, tworzących złożone warunki życia rodziny, wywierał również - jak przyjęto - wpływ na kulturę rodzicielstwa w czasach PRL. Na bazie przedstawionego opisu można zauważyć, że:

1. Rodzicielstwo kształtowały - podobnie jak kulturę rodziny - wpływy płynące ze strony kultury oficjalnej („,codziennej nadrzeczywistości”) oraz kultury nieoficjalnej (,codziennej rzeczywistości”);

2. Te dwa wymiary kultury generowały odmienne obrazy rodzicielstwa. Rodzicielstwo jako projekt ideologiczno-propagandowy różnił się od rodzicielstwa - praktyki codziennego życia;

3. Rodzicielstwo w środowisku miejskim różniło się od rodzicielstwa w środowisku wiejskim.

W celu zweryfikowania powyższych założeń postanowiono zrekonstruować obraz rodzicielstwa propagowany odgórnie, ukształtowany przez ideologię, propagandę i aktualną politykę $\mathrm{w}$ danym okresie PRL politykę państwa, aby następnie porównać go - chociaż w szerokim zarysie - do obrazu rodzicielstwa występującego w realnym środowisku codziennego życia, na przykładzie dużego miasta i wsi. Obraz rodzicielstwa, jako projektu ideologiczno-propagandowego, postanowiono zrekonstruować na podstawie treści dotyczących rodziny propagowanych w najbardziej popularnych czasopismach kobiecych PRL-u, czyli na podstawie tygodników społeczno-kulturalnych „Przyjaciółka” i „Kobieta i Życie”. Periodyki te ukazywały się na rynku już z końcem lat 40. (początkowo pod innymi tytułami) i wychodziły przez cały okres Polski Ludowej, a nawet po jej upadku. Ich nakład był ogromny, w przypadku „Przyjaciółki” wynosił od 180 tys. do 2 mln 164 tys. egzemplarzy tygodniowo (przy zapotrzebowaniu na 
trzy miliony tego czasopisma), a w odniesieniu do „Kobiety i Życie” od 330 do 700 tys. egzemplarzy tygodniowo. Tygodnik „Przyjaciółka” był adresowany do kobiet wiejskich i robotnic mniej wykształconych, a „Kobieta i Życie” do kobiet posiadających wyższe wykształcenie $\mathrm{z}$ dużych miast. W ten sposób podzielono kobiety w Polsce, na matki bardziej i mniej światłe w zakresie wiedzy oraz umiejętności pełnienia ról rodzicielskich. Poczytność tych czasopism wychodząca nawet poza ramy czytelnicze (np. powstawały kluby „Przyjaciółki” prowadzące działalność czytelniczą, dyskusyjną i towarzyską), jak również ponad czterdziestoletnia aktywność na rynku wydawniczym, pozwala przypuszczać o ich wpływie na świadomość rodzinną stałych czytelniczek (Sokół, 1998, 2003). Szczególnie poradniczy profil tych czasopism rodził duże zainteresowania wśród odbiorców. Przedmiotem badań uczyniono 104 numery tych czasopism z 1975 roku (po 52 numery z każdego czasopisma), które analizowano metodą badania zawartości mediów wg Berelsona, stosując w jej ramach analizę frekwencyjno-tematyczną oraz model procesu komunikacyjnego H. Lasswella. Szczególną uwagę skupiono w nim na treściach przekazu (co nadawca mówi i czego nie mówi?) oraz na kanale przekazu (w jaki sposób nadawca mówi i za pomocą jakich mechanizmów?). Stosowano też pytania filtrujące, pozwalające lepiej rozpoznawać treści o charakterze indoktrynacyjno-propagandowym.

Zupełnie inne źródła i metody leżały u podstaw rekonstruowania codzienności życia rodzinnego, czyli realnego funkcjonowania rodziny w latach 70., to jest w codzienności kształtującej się spontanicznie w toku naturalnych przemian społeczno-kulturowych. Bazę źródłową stanowiły w tym przypadku źródła pedagogiczne i socjologiczne, dokumenty osobiste, archiwalia oraz opracowania naukowe i historyczne wydane po 1989 roku. W dobrze źródeł przyjęto podejście interdyscyplinarne oraz podstawowe zasady weryfikacji źródeł. W badanych tekstach przyjęto podejście hermeneutyczne, pedagogiczno-historyczną perspektywę badawczą oraz analizę treści jako metodę badań. Podstawę teoretyczną dla potrzeb tego artykułu tworzyła środowiskowo-ekologiczna teoria Stevena E. Hobfolla (Conservation of Resources Theory, COR) (1989,44, s. 513-524; 2006, s.76) oraz koncepcja sytuacji psychologicznie trudnej Tadeusza Tomaszewskiego (1965, s. 244-249). Częściowo posłużono się też koncepcją modelu (rzeczywistości pożądanej) i wzoru (rzeczywistości realnej) Antoniny Kłoskowskiej (1959, nr 2, s. 58).

Na bazie powyższych założeń teoretycznych, dostępnych źródeł i teorii postawiono następujące główne pytanie badawcze: jaki sens i znaczenie nadawano rodzinie, a w niej rodzicielstwu w kulturze oficjalnej (czyli w wymiarze ideologiczno-propagandowym) oraz w kulturze nieoficjalnej (czyli w praktyce codziennego życia) w warunkach realnego socjalizmu lat 70 ? 
Pytanie to rozłożone zostało na pytania szczegółowe dotyczące takich zagadnień, jak: 1. stosunek do rodziny i jej roli w życiu człowieka; 2. stosunek dorosłych do posiadania dziecka; 3. postrzeganie dziecka jako wartości; 4. realizacja ról rodzicielskich; 5. metody oddziaływania na dziecko; 6. organizacja życia dziecka w środowisku rodzinnym; 7. stosunek rodziców do szkoły; 8. strategie manipulacji i adaptacyjno-obronne w realnym socjalizmie.

Poszukiwanie odpowiedzi na te zagadnienia stanowiło treść prowadzonych badań. Przedstawione poniżej wnioski dotyczą lat 70., chociaż w niektórych miejscach wywodu odwoływano się do lat 50, w których kształtowały się podstawy kultury realnego socjalizmu w Polsce. Lata 70. nazywane są ,złotym wiekiem komunizmu”, „gierkowskim skokiem modernizacyjnym”, ale najczęściej „realnym socjalizmem". Był to okres szczególny, w którym pierwsza połowa dekady zwiastowała sukces gospodarczy i nadzieje na lepsze życie, a druga połowa tej samej dekady gwałtowny kryzys i brak nadziei na normalność. Rodzina funkcjonowała więc w sytuacji psychologicznie trudnej, zarówno w kontekście kulturowego, jak i psychologicznego rozdarcia. W takich okolicznościach tworzyły się podstawy nowoczesnej rodziny i rodzicielstwa w Polsce. Poniżej przedstawione zostaną wnioski z badań obrazujące wizerunek rodzicielstwa propagowany w ideologii i w propagandzie komunistycznej (na poziome „oficjalnej nadrzeczywistości”) oraz w codziennym, realnym życiu rodziny miejskiej i wiejskiej (w codziennej rzeczywistości).

\section{RODZICIELSTWO W IDEOLOGII I PROPAGANDZIE „OFICJALNEJ NADRZECZYWISTOŚCI”}

W Polsce, po II wojnie - dekretem z dnia 25 września 1945 roku - narzucony został społeczeństwu laicki model małżeństwa i rodziny zbudowany na ideologii marksistowskiej. Tym samym wprowadzono obowiązek zawierania ślubu cywilnego, jak również możliwość uzyskania sądowego rozwodu. W dniu 1 stycznia 1946 roku nowe prawo weszło w życie. Od tego momentu w świadomości społeczeństwa ścierały się dwie przeciwstawne koncepcje małżeństwa i rodziny, czyli laicka i katolicka. W koncepcji laickiej, cele małżeństwa i rodziny miały być zawsze zharmonizowane z celami państwa laickiego. Zasada ta dotyczyła również rodzicielstwa, które powinno być świadome, czyli łączyć interes własny z potrzebami kraju. Takie kryterium determinowało wszystkie aspekty funkcjonowania w roli rodziców, jak również określało sens i znaczenie posiadania dziecka. Jego urodzenie miało być zawsze planowane i świadome, nie powinno przychodzić na świat bez woli rodziców, co oznaczało dopuszczalność antykoncepcji i aborcji (która 
wprowadzona została w dniu 27 kwietnia 1956 roku). Wartość dziecka wiązała się zawsze z jego członkostwem w grupie społecznej i w państwie - jako przyszłego budowniczego socjalizmu. Takie instrumentalne myślenie o dziecku funkcjonowało w całym okresie PRL-u. Przenikało ono również środowisko wychowawcze rodziny. Wychowanie realizowane $\mathrm{w}$ rodzinie, podobnie jak wychowanie poza rodziną, powinno być podporządkowane celom i normom społeczno-ustrojowym. Rodzina miała prawo i obowiązek wychowywania dzieci, ale przy współudziale państwa i w duchu uznawanej przez państwo ideologii społeczno-politycznej. W tym procesie niezbędne było jej współdziałanie i współpraca ze szkołą. Rodzina za swoje działania socjalizacyjno-wychowawcze na rzecz kształtowania przyszłych obywateli państwa socjalistycznego mogła liczyć - ze strony państwa - na ułatwienia w swoim codziennym funkcjonowaniu (Adamski, 1984, s. 192-204).

Powyższe założenia dotyczące rodzicielstwa wskazywały nie tylko na laicki model rodziny, ale też totalitarny ze względu na konieczność podporządkowania się wymogom ideologicznym i politycznym państwa. Ono bowiem ostatecznie decydowało o liczbie dzieci w rodzinie, kierunku i celach ich wychowywania, podporządkowaniu rodziny szkole oraz odgórnie ustalało, co dla rodziny jest dobre. Zarówno dobra osobiste małżonków, jak i dobro dziecka miały służyć państwu, które za posłuszeństwo i oddanie obiecywało rodzinie i jej członkom opiekę i pomoc.

Wytyczne ideologii marksistowskiej obowiązywały w całym okresie trwania systemu socjalistycznego w Polsce, pomimo postępujących od lat 60. przemian rodziny, zmierzających w kierunku nowoczesnej rodziny nuklearnej, która miała być jednak ,rodziną socjalistyczną”. Niestety, nawet w połowie lat 70. (tj. po trzydziestu latach trwania PRL) istniały problemy z definicją określenia „rodzina socjalistyczna”, a czytelnicy „Trybuny Ludu” jeszcze w 1976 roku pytali bezradnie: „Rodzina socjalistyczna - a więc jaka?”. Szeroką, wyliczającą definicję rodziny socjalistycznej przytoczył na łamach ankiety „Trybuny Ludu” w 1976 roku Mikołaj Kozakiewicz (Kosterkiewicz, 1976, s. 8) według którego:

\footnotetext{
Rodzina socjalistyczna to rodzina założona bezinteresownie w oparciu o motywację uczuciową, o równych prawach dla małżonków i odpowiednio do wieku - dzieci; rodzina otwarta na problemy innych, problemy społeczne, ideowe, państwowe; dająca równe możliwości startu życiowego swym członkom poprzez pracę i przygotowanie do życia w społeczeństwie; w wychowaniu współpracująca ze szkołą i organizacjami czy innymi instytucjami; wychowująca własnym przykładem i klimatem moralnym w duchu szlachetnych celów oraz jedności słów i czynów, teorii i praktyki (Kozakiewicz, 1976).
} 
Takie rozumienie rodziny socjalistycznej w połowie lat 70 . potwierdzało jej ideologiczną niezmienność oraz - w oczach ówczesnych ekspertów - atrakcyjność jako nowoczesnego modelu rodziny, który - ich zdaniem - był wciąż modelem idealnym, wymagającym jeszcze dużo czasu (tj. ok. 20 lat) do jego wdrożenia w codziennym życiu. Fakt ten thumaczono powolnością przemian zachodzących w sferze mentalnej, ale prawda była taka, iż duża część społeczeństwa nie identyfikowała się z nowym systemem politycznym lub robiła to tylko w określonym zakresie. Model rodziny socjalistycznej był w zasadzie ideologicznym pozorem, podobnie jak wiele cech „oficjalnej nadrzeczywistości”(Staniszkis, 1989, s. 8).

Dlatego też, aby przyspieszyć proces funkcjonowania modelu rodziny socjalistycznej, czasopisma kobiece, m.in. „Przyjaciółka” i „Kobieta i Życie”, przez cały okres PRL-u prowadziły szeroką działalność wychowawczo-indoktrynacyjną w tym zakresie. W latach 70. największą uwagę poświęcano modernizacji rodziny, która miała imitować modernizację rodziny zachodnioeuropejskiej, ale tak naprawdę była jej alternatywą opartą na modelu modernizacji sowieckiej. Była to bowiem modernizacja oparta na ideologicznej wersji marksizmu, centralnie planowana i sterowana, silnie upolityczniona. W odniesieniu do rodziny stanowiła ona narzędzie politycznego, odgórnego sterowania życiem jednostek i rodzin, wykluczająca wiele oddolnych inicjatyw w zakresie ich podmiotowości. W porównaniu do modelu zachodniego stanowiła ona jego selektywną i pozorną imitację, niemniej jednak inicjowała $\mathrm{w}$ życiu rodzin też pewne wartościowe trendy nowego stylu życia, np. partnerstwo w stosunkach małżeńskich i wychowawczych, demokratyzację relacji z dzieckiem, emancypację kobiety, wzrost świadomości jakości życia, czy też zwiększenie możliwości rozwoju dziecka w rodzinie wiejskiej.

Pomimo takich pozytywnych tendencji obraz małżeństwa i rodziny był w badanych czasopismach ukazywany w sposób jednostronny i często wypaczony jako źródło wielu trudności życiowych, szczególnie dla kobiet i dzieci. Mimo iż władze komunistyczne głosiły ważne znaczenie rodziny w życiu człowieka, w czasopismach jej obraz był zdecydowanie zredukowany i ukazywany od strony negatywnej, jako grupy słabej, wewnętrznie rozbitej i skonfliktowanej. Dlatego też należało - jak sugerował ukryty przekaz - oddać się pod opiekę władzy ludowej i harmonijnie z nią współpracować, czyli dostosowywać się do jej wymagań przez konformizm i adaptację. Takie przesłanie kierowano szczególnie do kobiet, dla których pomoc socjalistycznego państwa miała być jedynym ratunkiem przed wyzyskiem ze strony męża-ciemiężyciela, jak również drogą do uzyskania własnej niezależności i pozycji społecznej. Szansą dla kobiety była więc emancypacja. W latach 70. (podobnie jak i w latach 50.) wyrazem emancypacji kobiety i równocześnie wyznacznikiem jej sukcesu życiowego była praca posiadająca męski charakter, czyli - jak pisano - praca w „męskim zawodzie”. Taka praca 
wymagała politechnicznego wykształcenia, a jej wykonywanie budziło podziw i szacunek, w przeciwieństwie do pracy w ,zawodach kobiecych”. Emancypacja kobiety w latach 70. dotyczyła także innych sfer życia. Wymagała funkcjonowania w partnerskim związku małżeńskim, czyli posiadania „domowego” męża, który potrafiłby ją zastąpić w opiece nad dziećmi, gdy ona poświęca się karierze. Jako matka nie wykazywała gotowości do poświęceń na rzecz dziecka i rodziny, co odbierane było ze zrozumieniem. Lustrzanym odbiciem kobiety wielkomiejskiej była na wsi aktywna rolniczka i działaczka wiejska, która podejmuje męskie decyzje w organizacji gospodarstwa, kupuje maszyny i unowocześnia produkcję. Taki model sukcesu życiowego kobiety (zarówno w mieście jaki na wsi) - propagowany w czasopismach - na pierwszym miejscu stawiał jej role zawodowe i społeczne, a na drugim rodzinne. Sukces życiowy kobiety był w świetle przekazów funkcją jej pracy, troski ze strony panującej władzy oraz pomocy w rodzinie. Zawsze był silnie powiązany z losem socjalistycznego państwa i jego polityką. Niestety, mimo solennych obietnic wspierania kobiet przez komunistyczne władze, ich awans zawodowy był bardzo utrudniany, a zarobki za taką samą pracę, jaką wykonywali mężczyźni, znacznie niższe ${ }^{2}$. W tym sensie była to emancypacja bardziej pozorowana niż rzeczywista, która rozczarowała wiele kobiet. Niemniej jednak kształtowała ona nowe myślenie, w którym rodzina nie jest wyznacznikiem ich sukcesu życiowego, co najwyżej jego dopełnieniem. Tym samym obniżała się wartość macierzyństwa w życiu kobiet pracujących i generowała niechęć do posiadania większej liczby dzieci.

Dewaluacji wartości rodzicielstwa i dziecka sprzyjało także rozpatrywanie jego posiadania - na łamach prasy - w kategoriach kosztów i korzyści, głównie konsumpcyjnych. Do kosztów zaliczano fakt, iż utrzymanie dziecka ogranicza możliwość podniesienia standardu życia rodziny (np. kupna nowego telewizora), zmusza rodziców do wszelkich wyrzeczeń oraz jest źródłem większości konfliktów domowych. Postrzeganie dziecka w kategorii kosztów oddaje poniższy cytat:

Dziecko obniża standard życiowy rodziców: ekonomiczny i kulturalny. Uszczupla powierzchnię mieszkaniową, zasoby finansowe i zasoby wolnego czasu. Na jego rzecz trzeba zrezygnować z wypoczynku, przyjemności i - nierzadko - ambicji zawodowych. Szczęśliwi rodzice rzadko chodzą do kina lub teatru, rzadziej sięgają po książkę, ograniczają życie towarzyskie. Niedostępne stają się dawne atrakcje urlopowe, kończy się beztroska o dzień jutrzejszy. [...] Trzeba więc

\footnotetext{
${ }^{2}$ Oto przykładowa lista płac w jednym z zakładów pracy w1975 roku:,,Mistrz salowy zarabia 4300 zł. Chyba że jest kobietą - wtedy 3900. Kierownik w ruchu, czyli produkcji - 4900 zł, kobieta - 4300 . Kierownik w zarządzie - 5000, kobieta - 4400 zł. W Ministerstwie Przemysłu Lekkiego na 378 osób pracuje 213 pań. Naczelnik wydziału zarabia 6900 zł. Jedenaście naczelniczek po 6670 zł. Wicedyrektor departamentu - 8010. Cztery wicedyrektorki - po 7825” („Kobieta i Życie” 1975, nr 28).
} 
zmienić organizację dnia codziennego, znajdując w nim miejsce na nowe-liczne i uciążliwe obowiązki. Trzeba zrezygnować z kupna dla siebie tego i owego, co w młodzieżowym stylu odgrywało ogromną rolę, urastając do emblematów nowoczesności (Kobieta i Życie nr 28, 1975).

Taki stosunek do dziecka obniżał jego wartość i mógł zniechęcać małżonków do rodzicielstwa, co też spotykało się z krytyką, a dorosłych świadome rezygnujących z dzietności nazywano w prasie społecznymi egoistami. Generalnie w dziecku dostrzegano cenną wartość, integrującą związek małżeński (który bez dziecka uległby rozkładowi), cel małżeństwa, zabezpieczenie na starość, spełnienie marzeń i oczekiwań rodziców (których sami nie mogą zrealizować) oraz przyszłość socjalistycznego społeczeństwa.

W odniesieniu do prezentowanych na łamach czasopism wartości rodzinnych stosowano różne strategie manipulacyjne, np. dychotomiczne ich ukazywanie, tj. zarówno od strony pozytywnej, jak i negatywnej, w celu rozmycia ich sensu i wprowadzenia dorosłych w stan ogólnej dezorientacji. Ponadto w przedstawianiu zjawisk rodzinnych wprowadzano wyraziste kontrasty w celu wytworzenia podziałów w rodzinie. Dotyczyło to zwłaszcza ról rodzicielskich. Według czasopism, rodzicielstwo oznaczało wyłącznie macierzyństwo, bowiem ojcowie w przeciwieństwie do matek - ukazywani byli w sposób negatywny, jako osoby nieodpowiedzialne, niezainteresowane wychowywaniem dziecka, często też nieobecne fizycznie lub duchowo w rodzinie. W najbardziej pozytywnych ujęciach prezentowano ojców jako postaci bezbarwne, neutralne, podporządkowane matce lub „złote rączki”. Tylko tzw. „,nowy ojciec” - wytwór nowoczesnej rodziny socjalistycznej - mężczyzna umiejący zastąpić matkę w opiece i wychowywaniu dziecka, gdy ta była pochłonięta karierą, stanowił przypadek godny pochwały. $\mathrm{W}$ ten sposób podzielono rodziców na pełne oddania, pracowite, odpowiedzialne matki oraz nieudolnych, niedojrzałych, ojców. Podział utwierdził się na długo w świadomości społecznej i obniżał autorytet mężczyzn jako ojców. Ukazywanie takich dychotomii dotyczyło również mężczyzn jako mężów, których czasopisma przedstawiały jako alkoholików, tyranów, osobników o wąskich horyzontach intelektualnych, leni itp. Propagowanie takich kontrastów nie umacniało wizji rodziny jako wspólnoty.

Matki natomiast obdarzano dużym szacunkiem za rodzenie budowniczych nowego ustroju, ale krytykowano ich błędy wychowawcze, np. wyręczanie dzieci, zwalnianie z obowiązków domowych, nadmierne zaspokajanie potrzeb dzieci, a zaniedbywanie potrzeb własnych. Z największą jednak krytyką spotykała się gotowość matek do poświęceń na rzecz dzieci i rodziny. W tym zakresie ofiarna miłość matek była negatywnie oceniana, w przeciwieństwie do ich poświęcania się karierze zawodowej i politycznej. W pierwszym przypadku matki budziły 
politowanie, a w drugim podziw. Dochodziło przy tym do deformacji znaczenia sensu „ofiarnej miłości”, którą interpretowano jako przejaw braku rozsądku u kobiet. „Rozsądek” był bardzo często zalecaną formą zachowania, a właściwie „bytowania” w PRL (Doniec, 2019).

W całym obrazie rodzicielstwa mało miejsca poświęcono samemu dziecku i jego wychowaniu, poza faktem, iż zalecano rodzicom kształcenie politechniczne dzieci (w żadnym przypadku nie humanistyczne) potrzebne do budowy nowego, uprzemysłowionego kraju oraz ścisłą współpracę ze szkołą, czyli ukrytą zgodę na ich indoktrynację. Wychowanie w rodzinie oznaczało - według czasopism organizowanie dziecku bezpiecznych warunków bytu, w tym zapewnienie mu odpowiedniej diety i świeżego powietrza. W przekazach bardzo rzadko pojawiała się troska o kondycję psychiczną dziecka, chociaż coraz częściej podkreślano znaczenie budowania wzajemnego zaufania między rodzicami a dziećmi, jak również stosowanie demokratycznych metod wychowania. Wskazywało to na pewne procesy modernizacji $\mathrm{w}$ zakresie relacji rodzinnych. $\mathrm{Z}$ końcem lat 70 . w czasopismach coraz częściej pisano też o problemach wychowawczych dotykających rodzin i społeczeństwa, w dużych ośrodkach miejskich. Wcześniej przyjmowano bowiem ideologiczne założenie, że socjalistyczna młodzież nie sprawia kłopotów wychowawczych. W obliczu rosnącego chuligaństwa wśród młodzieży wielkomiejskiej, ten stan rzeczy był już nie do ukrycia. Jak widać, przekaz ideologiczno-polityczny i jego sterowanie rodziną, $\mathrm{w}$ tym rodzicielstwem, był stale obecny w modelu rodziny socjalistycznej, nawet w latach 70 . i w swych założeniach prawie niezmienny w całym okresie PRL Zmieniały się co najwyżej zewnętrzne formy przekazu i argumentacje, ale sens pozostawał ten sam. Propagowany w badanych czasopismach wizerunek rodzicielstwa był mało budujący pod względem psychologicznym i moralnym, poza praktycznymi poradami udzielanymi przez redakcję (typu gotowanie, szycie, higiena). Podobnie jak obraz rodziny ulegał redukcji, deformacji i nie pokazywał dojrzałych wzorów rodzicielstwa, np. tego co łączy rodziców (a nie tylko dzieli). Nie kształtował aksjologicznego myślenia u czytelników, tylko myślenie według potrzeb i korzyści, nie wzmacniał autorytetu rodziców, lecz go osłabiał. Nie dostrzegał też znaczenia wartości moralnych, tylko spłycał i rozmywał ich sens.

\section{RODZICIELSTWO W „CODZIENNEJ RZECZYWISTOŚCI”}

Całkiem inny obraz rodziny i rodzicielstwa ujawniły badania codziennego życia rodzin. Rodzina w świadomości społecznej postrzegana była jako najważniejsze środowisko życia i rozwoju człowieka, jak warunek jego stabilizacji życiowej oraz 
ochrona przed zagrażającym światem zewnętrznym (Doniec, 2019, s.133-140). Młodzież - jak wykazała Hanna Świda (1982, s. 217-247) - traktowała rodzinę wręcz jako azyl i oczekiwała od rodziców dystansowania się od reszty społeczeństwa i państwa. Takie oczekiwania groziły niekiedy eskapizmem i nie uważano ich za pozytywne (tak je oceniał m.in. wspomniany wcześniej Memoriał Episkopatu Polski z 1978 roku). W całym okresie PRL dostrzegano i podkreślano wielkie znaczenie rodziny jako wspólnoty wspierającej swoich członków w najtrudniejszych sytuacjach życiowych. Stanowiła ona - w odczuciach znacznej grupy społeczeństwa w PRL - fundament przetrwania ekonomicznego, kulturowego i moralnego. $\mathrm{W}$ potocznym rozumieniu, podstawą rodziny było małżeństwo i rodzicielstwo. Posiadanie dziecka postrzegano jako naturalny cel istnienia rodziny, a jego brak był boleśnie odczuwany i negatywnie interpretowany. Rodziny mające dzieci cieszyły się większą społeczną akceptacją niż małżeństwa bezdzietne, które budziły często dezaprobatę w swoich środowiskach. Optymalny model rodziny w oczekiwaniach społecznych składał się z 2-3 dzieci, czyli zakładał większą dzietność niż model propagowany w mediach. Mimo głoszonej emancypacji kobiet i egalitaryzacji stosunków rodzinnych (na skutek postępującej modernizacji rodziny) w świadomości społecznej występował dość tradycyjny sposób myślenia o rolach i obowiązkach związanych z płcią. A zatem realny model rodziny i rodzicielstwa był na poły jeszcze tradycyjny, podczas gdy model propagowany zdecydowanie nowoczesny, w rozumieniu rodziny socjalistycznej. Podstawową przeszkodą w posiadaniu większej liczby potomstwa oraz w realizacji ról rodzicielskich były trudne warunki życiowe, czego dowodziły wspomnienia i listy z tamtego okresu (m.in. Sołtysiak, 2004; „Czas Peerelu”, Archiwum Ośrodka Karta, 1994). Wśród skarg z tego okresu dominowały kwestie związane z brakiem różnego rodzaju zasobów zależnych od funkcjonowania państwa (np. mieszkań, podstawowych produktów potrzebnych do codziennego życia i zaopatrzenia dzieci, brak usług, niskie płace, zła komunikacja). Skarżono się też na rosnącą lawinowo drożyznę oraz brak wsparcia ze strony państwa w wielu sferach życia obywateli. Odczytywany w tej dziedzinie obraz różnił się diametralnie od obrazu rzeczywistości zawartej w prasie i oficjalnych dokumentach. Na skutek braku zasobów ówcześni rodzicie w swoich działaniach rozwojowo-wychowawczych koncentrowali się bardziej na przetrwaniu aniżeli na rozwoju, czego dowodzą realizowane przez nich różnorodne strategie oporu i przetrwania w warunkach socjalistycznej rzeczywistości (Doniec, 2019, s. 454-455). Dokonywali oni w tej dziedzinie często tragicznych wyborów, aby dać szansę dzieciom, przeważnie własnym kosztem. Do takich sposobów przetrwania - pokazujących kontekst realizacji zadań rodzicielskich - należały m.in. strategie: odkładania życia na później, odraczania własnych potrzeb i ambicji życiowych 
na rzecz rozwoju dzieci, podejmowanie wysiłków, aby nie było gorzej zamiast lepiej, ograniczania własnej podmiotowości do ram narzuconych przez system itp.

W takich warunkach życia dziecko stało się najbardziej pożądaną wartością i zasobem dla rodziców. W nim lokowali oni swoje niespełnione ambicje, aspiracje, marzenia oraz wiarę w lepszą przyszłość. Dlatego też jego warunki życia i wychowanie były warte - dla wielu rodziców - największych poświęceń. Kategoria kosztów związanych z posiadaniem dziecka - akcentowana mocno w przekazach propagandowych - nie miała decydującego znaczenia albo nie była wcale brana pod uwagę w wielu rodzinach. Większość rodziców starała się stworzyć dzieciom jak najlepsze warunki życia i rozwoju, niekiedy kładąc zbyt duży akcent na wartości konsumpcyjne aniżeli osobowe.

Ówczesna codzienność miała jednak złożoną strukturę i kulturę, także w zakresie rodzicielstwa. Obok rodzin charakteryzujących się wysoką kulturą wychowawczą, dużą dbałością o wszechstronną edukację dziecka, istniało wiele rodzin zaniedbujących potomstwo z powodu biedy, przepracowania czy braku czasu. Takie rodziny występowały zarówno w kręgach młodych, wykształconych, zapracowanych matek wielkomiejskich, które wychowywały swoje dzieci tylko w niedzielę, jak i w środowiskach wiejskich. Najbardziej zaniedbywane były dzieci miejskie, w środowisku robotniczym, które ze względu na wielozmianowość pracy rodziców pozostawały przez dużą część dnia bez kontroli i opieki. W innej sytuacji znajdowały się dzieci wiejskie, których jakość życia, co prawda niewiele się zmieniła od czasów przedwojennych, ale otoczone były kontrolą rodziny, z którą wspólnie ciężko pracowały. Dzieciństwo dzieci miejskich i wiejskich tworzyło nieporównywalne ze sobą światy życia i wychowania. W modelu rodziny - propagowanym w czasopismach - taki jaskrawy podział między miastem a wsią nie występował. Najlepsze warunki rozwojowe miały dzieci z rodzin inteligencji pracującej i wysoko wykwalifikowanych robotników, najgorsze - dzieci robotników niewykwalifikowanych.

Trudna „codzienna rzeczywistość” utrudniała pełnienie ról rodzicielskich, w tym kontrolę i sprawowanie opieki nad dziećmi oraz stwarzanie im właściwych możliwości rozwojowych. Największą przyczyną trudności wychowawczych w rodzinie był brak czasu rodziców na autentyczne zajęcie się dziećmi, który dotyczył - w latach 70. - niemal co drugiej matki oraz co trzeciego ojca i stanowił prawdziwy problem. Drugie miejsce w tym rankingu zajmowało zmęczenie rodziców, stanowiące zasadniczy powód ich nieskuteczności jako wychowawców. Problem zmęczenia, przedstawianego jako „niebotyczne zmęczenie”, „przemęczenie” albo „śmiertelne zmęczenie”, występował stale w opisach codzienności. Był to efekt braku wielu udogodnień (np. zbyt mała ilość przedszkoli, kłopoty z komunikacją, kolejki) i braku wspierania rodziny na co dzień, ale też wskaźnik 
psychicznego wyczerpania całego społeczeństwa trudnościami codziennego życia. Czasopisma i władze nie poruszały tego problemu, albo obarczały winą matki za złą organizację pracy w rodzinie, np. brak wyrobienia samodzielności u dzieci, zwalnianie z wielu obowiązków domowych itp. Za każdym razem, gdy pojawiały się trudności w codziennym życiu - winę za wszelkie niepowodzenia ponosiła tylko jednostka (nigdy państwo), w tym wypadku matka. Była to stała tendencja widoczna w przekazach propagandowych.

W niemal co drugiej rodzinie miejskiej dzieci nie miały dziennego rozkładu zajęć i pozostawały bez kontroli. Najbardziej pozbawione jej były dzieci robotników niewykwalifikowanych, których kultura wychowawcza pozostawała niższa aniżeli innych grup społecznych. W środowisku tym najczęściej dochodziło do różnorakich zaniedbań wychowawczych. Rodzice najrzadziej kontaktowali się ze szkołą, nawiązywali najmniej emocjonalne kontakty z dziećmi, mieli najniższe aspiracje dotyczące ich przyszłości i byli nastawieni na szybkie podejmowanie pracy zarobkowej przez młodzież. Stosowali też najbardziej prymitywne metody wychowawcze. Najmniej też dbali o rozwój i edukację potomstwa (Czapów, 1968, s. 253-331). Z kolei środowisko inteligencji wielkomiejskiej reprezentowało najwyższy poziom kultury wychowawczej, ale też było zróżnicowane. Występowały w nim matki tradycyjne, świadomie poświęcające się wychowaniu dziecka i w sposób przemyślany, przy wsparciu finansowym męża, konstruujące ambitne programy wychowawcze dla swych dzieci. Były też matki nowoczesne, często samotne, tzw. kobiety sukcesu, z wyższym wykształceniem, pracujące na cały etat (również w „męskich zawodach) przez większą część dnia. Ich praca zawodowa stanowiła podstawę utrzymania rodziny. Wykonywany zawód wymagał wysokich kwalifikacji i ciągłości (np. lekarki, artystki, naukowczynie). Dostarczał im również osobistej satysfakcji. Matki te miały wysoką świadomość wychowawczą, ale brakowało im sił i czasu na wychowywanie własnych dzieci, co przynosiło często negatywne skutki. Ta grupa kobiet korzystała też z pomocy babek, przejmujących niemal w pełni obowiązki na siebie (Doniec, 2019, s. 368-373).

Obraz środowiska wychowawczego rodziny wielkomiejskiej kontrastował silnie z środowiskiem wiejskim, w którym przywiązanie do tradycji i przedwojennych wzorów wychowawczych wciąż było widoczne w obszarze socjalizacji i w trudnych warunkach bytowych. Dzieciństwo rzadko stanowiło przedmiot głębszej refleksji rodziców. Matki wiejskie odznaczały się zaskakująco małą znajomością własnego dziecka (Kwaśniewski, 1971, s. 59), a ojcowie autorytarnym i prymitywnym stylem wychowania opartym na karze fizycznej. Dziecko traktowano często instrumentalnie i przedmiotowo. Na wsi wciąż nie miało ono dzieciństwa, prawa do czasu wolnego i własnych zainteresowań, a niekiedy nawet do wyboru własnej przyszłości zawodowej i współmałżonka. Pomimo wzrostu świadomości wychowawczej rodziców 
wiejskich (m.in. dzięki czasopismom kobiecym), rodzice nie wykazywali dużego zainteresowania nauką szkolną dziecka, chociaż dostrzegali jej znaczenie. W swoich decyzjach dotyczących przyszłości dziecka nadal kierowali się głównie interesem gospodarstwa, a nie dobrem dziecka. W wielu rodzinach dzieci nie mały żadnego wsparcia od rodziców, ani warunków do nauki. W okresach wzmożonych prac polowych rodzice - podobnie jak przed wojną - domagali się zwolnienia dzieci ze szkoły w celu pomocy w gospodarstwie. Dzieci wiejskie traktowano jak dorosłych, a zakres ich obowiązków i wiedza o gospodarstwie niewiele się różniły od wiedzy rodziców. Codzienne życie dziecka w tym środowisku było nieporównywalnie trudniejsze niż dziecka miejskiego, które często nie miało żadnych obowiązków domowych. Pomimo tych różnic środowiskowych, działania wychowawcze rodziców wiejskich, oparte na funkcjonowaniu we wspólnocie rodzinnej, kontroli oraz wychowywaniu przez pracę, wyrabiały u dzieci szereg pozytywnych cech, jak np. pracowitość, solidność, obowiązkowość, poczucie odpowiedzialności, duma z prawidłowego wykonania obowiązków, dojrzałość społeczna, samodzielność. Dlatego też wśród młodzieży wiejskiej znacznie rzadziej niż $\mathrm{w}$ miastach występowały zjawiska chuligaństwa i patologii społecznej. Mniejszy wpływ ideologii i propagandy w tym środowisku, jak również większy opór przed jej oddziaływaniem na dziecko (np. z obawy przed indoktrynacją ideologiczną rodzice wiejscy niechętnie zezwalali na wyjazdy dzieci na kolonie letnie) i rodzinę, wpływał integrująco na jej członków i nie osłabiał tak jej kondycji moralnej oraz kultury rodzicielstwa, jak miało to miejsce w miastach, chociaż nie była ona wysoka. Funkcjonowanie we wspólnocie i stała kontrola rodzicielska chroniła dzieci przed negatywnymi wpływami świata zewnętrznego, chociaż czasem też ograniczała ich rozwój. Najbardziej jednak rozwój umysłowy i fizyczny dziecka utrudniała, a nawet hamowała zbyt ciężka codzienna, wielogodzinna praca w gospodarstwie (Kawula, 1973, nr 56, s. 115). W takich okolicznościach procesy modernizacyjne - zachodzące na wsi w latach 70. - podnosiły jakość środowiska wychowawczego rodziny, w tym jakość życia dziecka wiejskiego. Takie tendencje niekoniecznie występowały w środowiskach wychowawczych rodzin wielkomiejskich.

\section{PODSUMOWANIE}

Przedstawione wnioski wykazały odmienność rodziny i rodzicielstwa jako modelu ideologiczno-propagandowego (propagowanego przez kulturę oficjalną) od rodziny i rodzicielstwa - wzoru realnej rzeczywistości (występującego w kulturze nieoficjalnej). Odmienność oddziaływań obydwu kultur stwarzała trudne psychologicznie warunki życia dla rodziny w PRL. Chcąc bowiem zachować swoje podstawowe zasoby, musiała ona stale dążyć do utrzymania równowagi 
między osłabiającymi ją wpływami kultury oficjalnej i chroniącymi ją wpływami kultury nieoficjalnej. Ten stan wywoływał stres, zmęczenie, niekiedy bezradność, ograniczał podmiotowość oraz możliwości rozwojowe rodzin. Rodzina żyła bowiem w konieczności ciągłej walki o przetrwanie, utrzymania swojej niezależności i zachowania najważniejszych zasobów. Funkcjonowała w sytuacjach psychologicznie trudnych, np. ograniczeń, redukcji, nieprzejrzystości, niepewności, zależności oraz braku nadziei.

W takich często ekstremalnych warunkach najważniejszą rolę do odegrania mieli rodzice, bowiem na nich spoczywał ciężar ochrony dzieci przed zgubnymi wpływami nowej ideologii i kultury. Trudy codziennego życia i wpływy ideologiczno-propagandowe osłabiały zdrowie psychiczne, fizyczne i kondycję moralną rodziców, a w konsekwencji także ich kulturę wychowawczą.

Kultura oficjalna, czyli „,codzienna nadrzeczywistość”, tylko pozornie nastawiona była na pomoc rodzinie, gdyż naprawdę skupiała się na kształtowaniu mentalności socjalistycznej i realizacji celów politycznych. W kulturze tej rodzina, rodzicielstwo i dziecko były narzędziem realizacji celów ideologiczno-politycznych socjalistycznego państwa. Kultura ta redukowała sens i znaczenie wartości rodzinnych, nadając im wyłącznie instrumentalny charakter. Wypaczała też rzeczywisty obraz rodziny pokazując ją od strony trudności, zagrożeń i patologii. Stosując różne strategie manipulacji, osłabiała w jednostkach struktury poznawcze, psychiczne, kształtowała postawy uległe i bierne.

Na szczęście istniała też kultura nieoficjalna („,codzienna rzeczywistość”), zakorzeniona w polskiej tradycji, która próbowała chronić rodzinę przed wpływami celowej indoktrynacji. Codzienność dostrzegała w rodzinie silną wspólnotę, niezbędną do osiągnięcia stabilizacji życiowej, wspierającą swoich członków w najtrudniejszych sytuacjach życiowych. Generowała ona postawy aktywne, solidarne, dążące do zmiany kultury oficjalnej, w tym różne strategie oporu i adaptacji do istniejących warunków życia. Rodzina występowała tutaj zawsze jako ważne środowisko rozwoju i wychowania (miejskie i wiejskie), zależne od posiadanych zasobów i warunków życia. Kultura codzienności stabilizowała rodzinę w warunkach kulturowego rozdarcia i kryzysu rzeczywistości.

W tym kontekście nasuwa się pytanie, jaki obraz rodziny i rodzicielstwa kształtuje dzisiejsza kultura liberalna, jak dalece jest on odmienny od obrazu rodziny propagowanego i realizowanego w kulturze realnego socjalizmu. 


\section{BIBLIOGRAFIA}

Adamski, F. (1984). Socjologia matzeństwa i rodziny. Warszawa: PWN.

Czapów, C. (1968). Rodzina a wychowanie. Warszawa: Nasza Księgarnia.

Czas Peerelu (1994). Warszawa: Archiwum Ośrodka Karta.

Doniec, R. (2019). Rodzina polska w kulturze realnego socjalizmu. Między ideologia a codziennościa. Kraków: Oficyna Wydawnicza „Impuls”.

Doniec, R. (2019). Między edukacją a indoktrynacją. Dobra rodziny na łamach czasopism kobiecych w Polsce lat 70. Na przykładzie czasopism „Przyjaciółka” i „Kobieta i Życie”. Pedagogika Społeczna, 4 (74), 199-222.

Hobfoll, S.E. (1989). Conservation of Resources: A New Attempt at Conceptualizing Stress. American Psychologist, 44.

Hobfold, S.E. (2006). Stres, kultura i społeczność. Psychologia i filozofia stresu, przeł. M. Kacmajor. Gdańsk: Gdańskie Wydawnictwo Psychologiczne.

Kobieta i Życie, 1975, 1-52.

Kawula, S. (1973). Działalność wychowawcza rodziny wiejskiej. Acta Universitatis Nicolai Copernici. Nauki Humanistyczno-Społeczne. Socjologia Wychowania, 56, 115.

Księga Listów PRL-u (2004). Część 3, 1971-1989, wybór i oprac. G. Sołtysiak. Warszawa: Baobab.

Kosterkiewicz, B. (1976). Rodzina socjalistyczna - a więc jaka? Warszawa: Książka i Wiedza.

KurzYnowski, A. (2000). Przemiany wzorów karier zawodowych kobiet w latach 1950-1889.

W: A. ŻarnowsKa, A. Szwarc (red.). Kobiety i praca. Wiek XX $i$ XIX. Warszawa: DIG.

KŁoskowska, A. (1959). Modele społeczne i kultura masowa. Przeglad Socjologiczny, 2.

KwaŚniewsKi, K. (1971). Społeczna i wychowawcza sytuacja dziecka na wsi opolskiej. Roczniki

Socjologii Wsi, 1 .

Memoriał Episkopatu Polski do Rządu PRL (1978). O rodzinie polskiej z dnia 8 stycznia 1978 roku, AAN, sygn. 284.

Przyjaciótka, 1975, 1-52.

Rodzina socjalistyczna - a więc jaka?( 1976), oprac. B. Kosterkiewicz. Warszawa: Książka i Wiedza.

SoKóŁ, Z. (1998). Prasa kobieca w Polsce w latach 1945-1995. Rzeszów:Wydawnictwo Wyższej Szkoły Pedagogicznej.

SokóŁ, Z. (2003). „Przyjaciółka” - tygodnik kobiecy. Studia Bibliologiczne Akademii Świętokrzyskiej, 7.

Staniszkis, J. (1989). Ontologia socjalizmu. Warszawa: Wydawnictwo In Plus.

Tomaszewski, T. (1965). O sytuacjach trudnych. W: Higiena psychiczna i nerwice dziecięce. Wrocław: Wydawnictwo PAN Zakład Narodowy im. Ossolińskich.

ŚwidA, H. (1982). Model rodziny w świadomości młodzieży. W: M. Jarosz (red.). Rodzina polska lat siedemdziesiatych. Warszawa: PWN.

Sztompka, P. (2002). Socjologia. Analiza społeczeństwa. Kraków: Wydawnictwo „Znak”. 


\title{
RODZINA I RODZICIELSTWO \\ W KULTURZE REALNEGO SOCJALIZMU - MIĘDZY IDEOLOGIĄ A CODZIENNOŚCIĄ
}

\begin{abstract}
STRESZCZENIE
Celem artykułu jest ukazanie sensu i znaczenia nadawanego rodzinie i rodzicielstwu w kulturze realnego socjalizmu w Polsce w latach 70 . W badaniach przyjęto założenie, iż w okresie realnego socjalizmu rodzina funkcjonowała w dwóch odrębnych wymiarach, czyli w kulturze oficjalnej i nieoficjalnej. Kultura oficjalna tworzona była odgórnie przez aparat władzy, ideologię marksistowską, celową indoktrynację i tworzyła rzeczywistość pozoru. Kultura nieoficjalna powstawała oddolnie, spontanicznie, na bazie kultury chrześcijańskiej i polskiej tradycji. Każda z tych kultur posiadała inną wizję rodziny i odmienny stosunek do wartości rodzinnych. Zasadnicze pytanie artykułu brzmi: jaki sens i znaczenie nadawano rodzinie i rodzicielstwu w kulturze oficjalnej oraz w kulturze nieoficjalnej w warunkach realnego socjalizmu lat 70 ? Odpowiedzi na to pytanie poszukiwano w oparciu o analizę różnego typu źródeł, m.in. czasopism kobiecych, dokumentów osobistych oraz dokumentów naukowych. W badaniach przyjęto perspektywę pedagogiczno-historyczną, metodę badania zawartości mediów oraz metodę analizy treści. Podstawę teoretyczną stanowiły: środowiskowo-ekologiczna teoria S.E. Hobfolla oraz koncepcja sytuacji trudnej autorstwa T. Tomaszewskiego.
\end{abstract}

Słowa kluczowe: rodzina; kultura; realny socjalizm; ideologia; codzienne życie.

FAMILY AND PARENTHOOD

IN THE CULTURE OF REAL SOCIALISM BETWEEN IDEOLOGY AND EVERYDAY LIFE

\section{SUMMARY}

The aim of the article is to show the sense and meaning given to the family and parenthood in the culture of real socialism in Poland in the 1970s. The research assumed that during the period of real socialism, the family were functioning in two separate dimensions, i.e. in the official and unofficial culture. Official culture was created top down by the apparatus of power, Marxist ideology, deliberate indoctrination, and it created the reality of appearances. Unofficial culture was created from below, spontaneously, on the basis of Christian culture and Polish tradition. Each of these cultures had a different vision of the family and a different attitude towards family values. The main question of the article is: what sense and meaning were given to the family and parenthood in it within the official culture and in the unofficial one under the conditions of real socialism of the 1970s? The answer to this question were sought based on the analysis of various types of sources, including women's magazines, personal documents and scientific materials. The research adopted the pedagogical and historical perspective, the method of media content research and the method of content analysis. The theoretical basis for the analyzes was the environmental and ecological theory of S.E. Hobfoll and concept of a difficult situation by T. Tomaszewski.

Keywords: family; culture; real socialism; ideology; everyday life. 